\author{
dr Magdalena Białek \\ Uniwersytet Wrocławski \\ Instytut Filologii Germańskiej \\ tel. 713752452 \\ e-mail: magdalena.bialek@uwr.edu.pl
}

\title{
INPUT W DYSKURSIE KLASOWYM NA PRZYKLADZIE JEZZYKA NIEMIECKIEGO JAKO OBCEGO W SZKOŁACH PONADGIMNAZJALNYCH
}

\begin{abstract}
STRESZCZENIE
Przedmiotem rozważań niniejszego artykułu jest input w dyskursie klasowym na przykładzie języka niemieckiego jako obcego w szkołach ponadgimnazjalnych.

W części teoretycznej dokonano krótkiego przeglądu literatury na temat roli i znaczenia prymarnych danych językowych w procesie uczenia się języka obcego w warunkach formalnych. Porównano również procesy akwizycji języka pierwszego z procesami uczenia się języka obcego. Ponadto przedstawiono opozycyjne stanowiska badaczy na temat stosowania języka ojczystego i języka obcego w procesie glottodydaktycznym. W części empirycznej przedstawiono wyniki badań, których celem było przeanalizowanie jakości inputu charakterystycznego dla dyskursu klasowego na lekcji języka obcego w szkołach licealnych.

Przeprowadzone badanie pokazało, że polscy germaniści nie są ekspertami w kreowaniu środowiska immersyjnego na lekcji języka obcego. Okazało się, że bardzo często wiele sekwencji lekcyjnych odbywa się w języku ojczystym. Ponadto nauczyciele rzadko stosują techniki pracy i materiały, które w sposób szczególny zapewniają tzw. dobry input. Co szczególnie dziwi, germaniści nie często zachęcają młodzież do kontaktu z językiem niemieckim w warunkach pozalekcyjnych. Nauczyciele wydają się nie dostrzegać potencjału dostępnych materiałów i mediów w tym zakresie. Bardzo rzadko umożliwiają uczniom słuchanie niemieckiej muzyki i oglądanie niemieckojęzycznych filmów. Ponadto wyniki badania nie pozwalają zauważyć, jakoby nauczyciele w jakiś szczególny sposób dbali o odpowiednią jakość i ilość inputu na lekcji języka niemieckiego. Ich świadomość w tym zakresie wydaje się być niewielka.
\end{abstract}


Artykuł kończy postulat o potrzebie prowadzenia bardziej szczegółowych badań w opisywanym zakresie.

Słowa kluczowe: input, dane wejściowe, akwizycja, uczenie się w warunkach formalnych

\section{SUMMARY}

\section{Language input in any class discourse during classes of German language taught as a foreign language in upper-secondary schools}

This article focuses on language input presented in any class discourse during classes of German language taught as a foreign language in upper-secondary schools.

In the theoretical part of the article a short review of literature discussing the role and meaning of primary linguistic data in the process of learning a foreign language in formal conditions was conducted. Next processes which occur during first language acquisition were compared to the processes involved in foreign language acquisition. Moreover, contrary attitudes of the researchers towards applying mother tongue and foreign language in foreign language teaching were presented. In the empirical part the results of the research were presented. The aim of the research was to analyze the quality of typical class discourse input provided during a foreign language lesson in comprehensive upper-secondary schools.

The research showed that Polish teachers of German language are not experts on creating immersive environment during foreign language classes. It occurred that frequently many lesson sequences are carried out in the mother tongue of students and a teacher. Teachers rarely apply teaching techniques and use materials which provide enough good language input. It is also astonishing that German language teachers do not encourage young learners to come into contact with real German language in out-of-the classroom situations. They seem not to take into account how great the advantages of using available materials and media might be. Furthermore, they do not enable their students to listen to German music or watch German films, either. The results of the research reveal that teachers of German are not greatly concerned with appropriate quality and amount of language input during lessons. Their awareness of all these issues is not deep enough.

The main conclusion of the article is to imply the necessity of conducting more detailed research in the described area.

Keywords: input, foreign language learning, mother tongue 


\section{Wstęp}

Akwizycja języka ojczystego jest naturalnie przebiegającym procesem polegającym na restrukturyzacji języka, czyli ciągłej rewizji reguł hipotetycznych ${ }^{1}$. Stawianie hipotez językowych oraz ich weryfikowanie poprzez konfrontowanie własnych produkcji z danymi pochodzącymi z otoczenia jest podstawowym elementem akwizycji języka ojczystego ${ }^{2}$. Permanentna ekspozycja na język jest więc w sposób naturalny wystarczającym warunkiem osiągania biegłości komunikacyjnej. Innymi słowy, rozumienie i wytwarzanie aktów komunikacyjnych staje się możliwe dzięki osobistej, specyficznej dla każdego człowieka umiejętności przetwarzania wiedzy, której jedynymi dostępnymi reprezentacjami są wyrażenia językowe ${ }^{3}$. O ile procesy i warunki akwizycji języka pierwszego nie budzą wątpliwości, to szereg niejasności pojawia się w przypadku nauki języka obcego. Oczywiste jest, że procesów uczenia się języka obcego nie można tłumaczyć procesami akwizycji języka ojczystego. Można je jednak w pewnym stopniu porównywać i szukać punktów wspólnych. Czyni to Krashen ${ }^{4}$, którego hipotezy cieszyły się i w dalszym ciągu cieszą dużą popularnością wśród dydaktyków, choć dzisiaj potrafimy już wskazać ich słabe punkty (por. postulaty interakcjonistów). Uznając niemożność postawienia znaku równości między akwizycją języka ojczystego a uczeniem się języka obcego w warunkach formalnych, nie można jednocześnie zaprzeczyć, że również w kontekście glottodydaktycznym prymarne dane językowe są warunkiem sine qua non jego skuteczności.

W niniejszym artykule podjęta zostanie próba analizy prymarnych danych językowych na lekcji języka niemieckiego w dolnośląskich szkołach. Prezentacja wyników badań własnych poprzedzona zostanie przeglądem literatury na temat danych wejściowych w dyskursie szkolnym.

\section{Ekspozycja na język versus interakcja w procesach uczenia się formalnego}

Reprezentowane przez Krashena w latach 80. poglądy na temat roli i znaczenia danych wejściowych $\mathrm{w}$ procesach nabywania języków, zostały z biegiem

1 W. Klein, Second Language Acquisition, Cambridge 1986, s. 149.

2 Por. A.-C. Berthoud, B. Py, Des linguistes et des enseignants. Maîtrise et acquisition des langues seconds, Berne 1993.

3 F. Grucza, Jęzki ludzkie a wyrażenia językowe, wiedza a informacja, mózg a umyst ludzki, [w:] Podejścia kognitywne w lingwistyce, translatoryce i glottodydaktyce. F. Grucza, M. Dakowska (red.), Warszawa, 1997, s. 7-21.

4 S. D. Krashen, The Input Hypothesis: Issues and Implications, New York 1985. 
czasu zrelatywizowane. Przekonanie twórcy teorii monitora jakoby rozumienie wypowiedzi warunkowało rozwój systemu językowego uczącego się, a produkcja językowa była następstwem tegoż rozumienia, zostało częściowo zanegowane przez poglądy innych badaczy. Warto w tym kontekście zwrócić uwagę na hipotezę interakcyjną Longa ${ }^{5}$, w której podkreśla się rolę negocjacji znaczeń i modyfikacji interakcyjnych w ułatwianiu zrozumienia materiału językowego, odrzucając tym samym twierdzenie Krashena jakoby produkcja językowa nie odgrywała większej roli. Ponadto rola nieświadomego uczenia się została niejako zanegowana przez hipotezę świadomego spostrzegania (ang. noticing hypothesis), zgodnie z którą przyswojenie języka obcego wymaga zwrócenia uwagi na określone formy, tak aby uczący się mógł porównać zamierzone lub już wyartykułowane wypowiedzi $\mathrm{z}$ ich poprawnymi odpowiednikami i w ten sposób dostrzec luki w swojej wiedzy językowej (ang. notice the gap) (Schmidt 1990, $2001^{7}$, za: Pawlak 2009) ${ }^{8}$. Interakcja jest również postrzegana jako kluczowy mechanizm w przyswajaniu języka obcego przez zwolenników teorii socjokulturowej (ang. sociocultural theory), szczególnie w sytuacji, gdy odbywa się ona w tzw. strefie najbliższego rozwoju (ang. zone of proximal development), umożliwiając mniej zaawansowanym użytkownikom języka konstruowanie wypowiedzi z pomocą bardziej zaawansowanych rozmówców (Lantolf $2006^{9}$, za: Pawlak 2009) ${ }^{10}$. Również inni badacze potwierdzają znaczenie konceptów wyrosłych na gruncie teorii W. Wygotskiego (W. Grabe i F. L. Stoller $1997^{11}$, M. Swain i P. Deters $2007^{12}$ ).

Pewnym kompromisem w dyskusji „input czy interakcja” wydaje się być stanowisko Gass ${ }^{13}$, zgodnie z którym niezbędnymi elementami w nauce języka

5 M. H. Long, Linguistic and conversational adjustments to non-native Speakers, „Studies in Second Language Acquisition" 1983, 5, s. 177-193.

6 R. Schmidt, The role of consciousness in second language learning, „Applied Linguistics” 1990, 11, s. $17-46$.

7 R. Schmidt, Attention, [w:] Cognition and second language instruction, P. Robinson (red.), Cambridge 2001, s. 3-32.

8 M. Pawlak, Rola nauczyciela w kształtowaniu procesów interakcyjnych podczas lekcji języka obcego, [w:] Nauczyciel języków obcych dziś i jutro, M. Pawlak, A. Mystkowska-Wiertelak, A. Pietrzykowska (red.), Poznań-Kalisz 2009, s. 311-337.

9 J. Lantolf, Sociocultural theory and second language learning, Oxford 2000.

10 Ibidem, s. 315.

11 W. Grabe, F. L. Stoller, Content-Based Instruction: Research Foundations, [w:] The Content-Based Classroom. Perspectives on Integrating Language and Content. M. A. Snow, D. M. Brinton (red.), White Plains, NY 1997, s. 5-21.

12 M. Swain, P. Deters, "New" mainstream SLA theory: expanded and enriched, „The Modern Language Journal" 2007, 9, s. 820-836.

13 S. Gass, Input and interaction, [w:] Handbook of second language acquisition, C. J. Doughty, M. H. Long (red.), Oxford 2003, s. 224-255. 
obcego są: odpowiednia ilość danych wejściowych, informacja zwrotna na temat poprawnych i niepoprawnych wypowiedzi formułowanych przez uczącego się oraz produkcja językowa umożliwiająca przetwarzanie danych.

\section{Język ojczysty versus język obcy w warunkach szkolnych}

Rozważania na temat jakości i ilości inputu w dyskursie klasowym wiążą się w sposób naturalny z dyskusją na temat użycia języka ojczystego i języka obcego w warunkach formalnej nauki. Mimo dość długiej tradycji tejże dyskusji nie doczekała się ona jednoznacznego rozstrzygnięcia, czy to na korzyść dydaktyki monolingwalnej wykluczającej użycie języka ojczystego, czy też bilingwalnej, gdzie język ojczysty uznać można za katalizator procesów przyswajania języka obcego. Niektórzy zwolennicy podejścia komunikacyjnego (Krashen 1982 ${ }^{14}$, Prabhu $1987^{15}$ ) opowiadają się za upodobnieniem dyskursu pedagogicznego do rozmowy w warunkach naturalnych. Wydaje się to być jednak trudnym zadaniem, gdyż z samej definicji są to dwie diametralnie różne sytuacje. Na trzy aspekty determinujące brak podobieństwa między nimi wskazuje Niżegorodcew ${ }^{16}$. Po pierwsze, dyskurs klasowy jest determinowany przez osobę nauczyciela, który decyduje o kierunku oraz rodzaju interakcji. Po drugie, decyduje on również o rodzaju i częstotliwości obcojęzycznego inputu. Trzecim aspektem przytaczanym przez Niżegorodcew, jest rozbieżność dwóch dyskursów, którą determinują sztywne normy szkolne narzucone przez określony kontekst edukacyjny. Innymi słowy dyskurs klasowy jest często pozbawiony interakcji, która wytwarzałaby się wskutek autentycznych potrzeb komunikacyjnych jednej ze stron. Środkiem zaradczym w tej sytuacji jest stworzenie uczniom możliwości negocjowania znaczeń i wspólnego konstruowania dyskursu, stosowanie głównie pytań, na które nauczyciel nie zna odpowiedzi czy też umożliwienie uczniom wyboru i rozwinięcia tematu, stymulowanie aktywnego udziału w zajęciach, kiedy uczący się są na to gotowi ${ }^{17}$.

Realizacja powyższych postulatów zakłada posługiwanie się językiem docelowym. Propagowanie jednojęzyczności nie jest jednak „wymysłem” przedstawicieli podejścia komunikacyjnego. Już w metodzie bezpośredniej zakładano możliwość opanowania języka obcego na wzór i podobieństwo akwizycji języka pierwszego

14 S. D. Krashen, Principles and practice in second language acquisition, New York 1982.

15 N. S. Prabhu, Second language pedagogy, Oxford 1987.

16 A. Niżegorodcew, Input for instructed L2 learners: the relevance of relevance, Clevedon 2007.

17 R. Ellis, The study of second language acquisition. Oxford 1994. 
pod warunkiem, iż obcojęzycznemu inputowi towarzyszyła będzie odpowiednia demonstracja, stanowiąca kontekst ułatwiający zrozumienie przekazu obcojęzycznego oraz właściwy język. Zwolennicy podejścia monolingwalnego wychodzą ponadto z założenia, że każde użycie języka ojczystego zubaża środowisko obcojęzyczne, co jest niekorzystne szczególnie wtedy, kiedy lekcja języka obcego jest jedyną okazją dla uczniów do kontaktu z językiem obcym (myślę, że tak jest w przypadku uczniów uczących się języka niemieckiego w Polsce). Ograniczanie ekspozycji na język obcy rozumiane jako negatywne zjawisko było przedmiotem wielu badań, np. Macdonald $1993^{18}$, Cook 2001 ${ }^{19}$, Turnbull 2001 ${ }^{20}$, Littlewood i B. Yu $2011^{21}$. Również Deller i Rinvolurci ${ }^{22}$ postulują użycie przede wszystkim języka obcego. (Akceptują przy tym trzy sytuacje zasadnego użycia języka ojczystego - porównanie systemów gramatycznych obu języków w przypadku uczniów początkujących oraz w przypadku tłumaczenia zdań, gdy określone zagadnienie gramatyczne przysparza uczniom trudności).

W opozycji do przekonań zwolenników podejścia monolingwalnego pozostają poglądy zwolenników technik bilingwalnych, dla których wykorzystywanie języka ojczystego jest pożądanym elementem procesu nauczania języka obcego (Auerbach 1993'23, Macaro $1997^{24}$, Eldridge $1996^{25}$, Schweer 1999²6).

Niezależnie od przytoczonych argumentów nie można wyeliminować języka ojczystego z procesu formalnej nauki. Jest on integralną częścią uczącego się podmiotu i jako taka będzie zawsze w mniejszym lub większym stopniu uczestniczyć $\mathrm{w}$ procesie przetwarzania informacji i rekonstruowaniu wiedzy. Dzisiaj wydaje się to być jedyna droga poznania (por. założenia konstruktywistów). Input natomiast, bez którego nauka języka obcego nie byłaby możliwa, staje się surowcem do przetwarzania informacji oraz gospodarowania jego zasobami poznawczymi ${ }^{27}$.

18 C. Macdonald, Using the target language, Cheltenham, UK 1993.

19 V. Cook, Second language learning and language teaching (3rd ed.), London 2001.

20 M. Turnbull, There is a role for the L1 in second and foreign language teaching, but..., „The Canadian Modern Language Review" 2001, 57, s. 531-540.

21 W. Littlewood, B. Yu, First language and target language in the foreign language classroom, „Language Teaching" 2011, 44 (1), s. 64-77.

22 S. Deller, M Rinvolucri, Using the Mother Tongue, London-Addlestone 2002.

23 E. Auerbach, Reaxamining English anly in the ESL classroom, „TESOL Quartely” 1993, 27 (1), s. 9-32.

24 E. Macaro, Target language, collaborative learning and autonomy, Clevedon 1997.

25 J. Eldridge, J., Code - switching in a Turkish secondary school, „ELT Journal” 1996, 50 (14), s. 303$-311$.

26 W. J. Schweer, Using L1 in the L2 classroom, „English Teaching Forum”, 1999, 37 (2), s. 6-9.

27 M. Dakowska, Teaching English as a Foreign Language. A Guide for Professionals. Warszawa 2007. 


\section{Jak tworzyć środowisko bogate w dane wejściowe?}

Jaki powinien być input? Na to pytanie odpowiada Krashen w swoich hipotezach: zrozumiały, dostarczony w odpowiedniej ilości, najlepiej o jeden „poziom” trudniejszy, niż ten na jakim jest uczący się i przekazany w dobrej atmosferze, która nie dopuszcza do aktywizacji filtra afektywnego, co w rezultacie stwarza środowisko sprzyjające procesowi uczenia się. Dobra ekspozycja na język uwzględnia ponadto różnorodność kontekstów, w jakich prezentowane są dane wejściowe. Za dobre źródło „pozyskiwania” danych językowych uważa Ellis teksty pisane ${ }^{28}$, które w przeciwieństwie do mówionych umożliwiają czytającemu indywidualną rekonstrukcję danych językowych w dowolnym, przystosowanym do własnych warunków poznawczych tempie, co w dalszej konsekwencji ułatwia stawianie hipotez językowych i ich weryfikację, a to z kolei otwiera drogę do prawidłowej produkcji językowej. W tym kontekście $\mathrm{Nagy}^{29}$ przekonuje, że przeciętny uczący się może w ciągu roku „pozyskać” z tekstów pisanym ponad 1000 jednostek leksykalnych. Zalety ekstensywnego czytania podkreślają również inni badacze.

Bestrzyński i Szymiec ${ }^{30}$, posługujący się formułą „kształcenia odtwarzającego środowisko immersyjne”, również udzielają kilku wskazówek. Jedno z narzędzi, które opisują, to technika dramy, która może być wykorzystana jako technika uzupełniająca klasyczne programy nauczania bądź też centralna część każdych zajęć w ramach programu edukacyjnego opartego na akwizycji kompetencji językowych. Ponadto, biorąc pod uwagę ograniczone możliwości czasowe na lekcji języka obcego, proponuje się rozszerzenie aktywności uczących się poza klasę, zanurzenie w języku pisanym poprzez ekstensywne czytanie z wykorzystaniem zarówno tekstów narracyjnych jak i eksplanatorycznych. Rozumie się przez to wprowadzenie do codziennej aktywności czytania minimum czterech stron tekstu w formacie A4 przy założeniu, że stopień trudności tekstu jest odpowiedni dla ucznia, a jego przeczytanie zajmuje ok. 30 minut dziennie ${ }^{31}$.

\footnotetext{
28 R. Ellis, op. cit.

29 W. Nagy, On the role of context in first- and second-language vocabulary learning, [w:] Vocabulary: description, acquisition and pedagogy, N. Schmitt, M. Mccarthy (red.), Cambridge 1997.

30 W. Bestrzyński, R. Szymiec, Nauka języka obcego - drama jako składnik immersji, „Neodidagmata” 2008, 29/30, s. 163-181.

31 Ibidem, s. 174.
} 


\section{Opis badania}

Badanie na temat inputu na lekcjach języka niemieckiego w szkołach ponadgimnazjalnych przeprowadzone zostało w marcu i kwietniu 2015 roku wśród studentów II roku studiów pierwszego stopnia na kierunku filologii germańskiej realizujących ścieżkę przygotowującą do wykonywania zawodu nauczyciela. W badaniu wzięło udział 65 studentów. Zadanie respondentów polegało na uzupełnieniu kwestionariusza ankiety składającego się z dwóch części ${ }^{32}$. W pierwszej części respondenci proszeni byli o udzielenie odpowiedzi na pytania zamknięte, natomiast druga część składała się z pytań otwartych. Podkreślić należy, że z respondentami omówiono wcześniej rolę inputu językowego (co wynikało z programu przedmiotu) i zapoznano z podstawowymi pojęciami w tym zakresie. Studenci otrzymali wydruk ankiety i poproszeni zostali o jej wypełnienie w nieograniczonym przez prowadzącego czasie. Badanie przebiegło bardzo sprawnie. Spośród 65 rozdanych kwestionariuszy ankiety, analizie poddanych zostało 64 . Jednego zwróconego arkusza nie można było poddać analizie z powodu odpowiedzi respondenta na tylko jedno z 18 pytań. Tę ankietę uznano za nieważną.

\section{Budowa kwestionariusza ankiety}

Pierwsza część ankiety składała się z 18 stwierdzeń z kafeterią dysjunktywną, a respondenci proszeni byli o zakreślenie właściwej dla nich odpowiedzi przy jednej z następujących możliwości: nigdy, bardzo rzadko, rzadko, czasami, często, bardzo często. Każde stwierdzenie opisywało działania lub zachowanie nauczyciela, do których sformułowano 9 kryteriów. Kryteria te nie zostały podane do wiadomości respondentów ${ }^{33}$.

- Komunikacja monolingwalna.

- Optymalizacja językowych danych wejściowych.

- Sposób prezentacji słownictwa przez nauczyciela.

- Elementy podejścia narracyjnego stosowane przez nauczyciela na lekcji języka niemieckiego.

- Teksty autentyczne jako źródło inputu.

- Zachęta do kreowania środowiska immersyjnego w warunkach innych niż lekcja.

- Zabiegi metodyczne o małej wartości inputu.

- Dostosowanie inputu do potrzeb uczniów.

$32 \mathrm{~W}$ niniejszym artykule przedstawione zostaną wyniki tylko pierwszej części ankiety.

33 W załączniku zamieszczona zostanie pełna wersja kwestionariusza ankiety. 


\section{Wyniki badania}

\section{Komunikacja monolingwalna}

Analiza pierwszego pytania pokazuje, iż $20 \%$ nauczycieli bardzo często posługiwało się językiem docelowym, a 46\% często. Bardzo rzadko i rzadko języka niemieckiego używało 18\% nauczycieli, a 16\% germanistów czasami.

66-procentowy odsetek nauczycieli realizujący w dyskursie klasowym akty komunikacyjne w języku docelowym wydaje się być optymistycznym wynikiem. Każda próba kreowania środowiska immersyjnego, czyli środowiska bogatego w input językowy, przemawia zawsze na korzyść uczących się i przynosi wymierne korzyści, o czym przekonują psycholingwistyczne teorie. W przypadku uczenia się języka obcego metodami tradycyjnymi zapamiętany zostaje abstrakcyjny model takiego języka, a skorzystanie z niego (czyli na przykład produkcja językowa) wymaga od uczącego się czasu i namysłu. Natomiast kompetencje językowe nabyte dzięki akwizycji w środowisku immersyjnym reprezentują inną jakość. Słownictwo i struktury gramatyczne nie są już przechowywane w obszarach pamięci koncepcyjnej, ale językowej. Przykładem różnicy między tymi dwoma podejściami do zdobywania kompetencji językowych w sposób klasyczny i poprzez imersję może być fakt samodzielnego pojawiania się właśnie na skutek akwizycji struktur języka obcego w myślach, gdzie do tej pory wszystkie zdania były formułowane w języku rodzimym ${ }^{34}$.

Z drugiej jednak strony 66-procentowy wynik może rozczarowywać. Wszak mowa o poziomie licealnym - stąd uzasadnione byłyby większe oczekiwania, jeśli chodzi o frekwencyjność stosowania języka docelowego. Tutaj konieczna staje się refleksja nad przyczyną takiego stanu rzeczy. Dlaczego stosunkowo tak mało nauczycieli czyni narzędziem swojej pracy język docelowy? Przyczyn może być wiele - choćby brak motywacji nauczyciela do podejmowania większego trudu, który z reguły implikuje użycie języka obcego, nieświadomość wzrostu wymiernych korzyści językowych powodowanego zwiększeniem ilości inputu, strach przed niepodołaniem w sytuacji półautentycznej, czy też brak doświadczenia itd. Te spekulacje wymagałyby oczywiście empirycznej weryfikacji.

Pytanie drugie dostarcza informacji o posługiwaniu się przez nauczyciela językiem docelowym podczas objaśniania zasad gramatycznych. Okazuje się, że 59\% nauczycieli wyjaśniała materiał gramatyczny w języku polskim bardzo często, a $20 \%$ często. $20 \%$ pedagogów objaśniała gramatykę w języku polskim czasami, a $1 \%$ bardzo rzadko. Język ojczysty jest więc podstawowym narzędziem tłumaczenia zasad gramatycznych. Nie negując podejścia dedukcyjnego w nauczaniu

34 Ibidem, s. 163-181. 
gramatyki i rozumiejąc jego nieodzowność w określonych przypadkach, zasadne wydaje się jednak pytanie o tak duży odsetek nauczycieli „wyręczających swoich uczniów w myśleniu" i stosujących nagminnie podawcze metody nauczania sprowadzające się w swoich mechanizmach działania do dawno przebrzmiałych modeli nauczania, kiedy to uczeń będący „, białą, niezapisaną kartą”, był „tworzony i kreowany" przez system szkolny, w tym przede wszystkim nauczycieli. Przy tej okazji nasuwa się również pytanie, na ile problem transmisyjnego przekazywania wiedzy jest specyficzny dla, na przykład, przekazu gramatyki obcojęzycznej, a na ile mógłby być on rozumiany jako problem globalny polskiej edukacji.

O ile w przypadku wprowadzania nowego materiału gramatycznego widać wyraźną przewagę w stosowaniu przez nauczycieli języka polskiego nad niemieckim, tak w przypadku pracy ze słownictwem odpowiedzi nie są już tak wysoce spolaryzowane i rozkładają się na wszystkie sześć możliwych propozycji odpowiedzi. I tak, zgodnie z opiniami respondentów 18\% nauczycieli nie tłumaczy nigdy zwrotów leksykalnych w języku niemieckim, 16\% wykorzystuje do tłumaczenia język niemiecki bardzo rzadko, 13\% rzadko, a 30\% czasami. Bardzo często komunikację monolingwalną $\mathrm{w}$ tłumaczeniu uczniom zagadnień leksykalnych stosuje $10 \%$ nauczycieli, a często $13 \%$ germanistów.

Jak widać, postulowany obecnie przez zwolenników podejścia komunikacyjnego paradygmat jednojęzyczności nie wydaje się być realizowany przez nauczycieli języka niemieckiego w zbyt dużym stopniu. Uznając za Butzkammem ${ }^{35}$, iż język ojczysty jest rzeczywiście w niektórych sytuacjach „sprzymierzeńcem” uczących się języka obcego, to jednak dziwić może fakt, że stosunkowo niewielki odsetek nauczycieli posługuje się językiem docelowym w klasach licealnych.

\section{Optymalizacja językowych danych wejściowych}

Formułując stwierdzenia do ww. kategorii bazowano na założeniu, iż dane językowe warunkują wykorzystanie przez uczących się intuicyjnych mechanizmów przyswajania języka ${ }^{36}$. Jednak, aby zostały uruchomione wewnętrzne procesy rozumienia, które są sterowane wrodzonym mechanizmem przyswajania języka, input musi mieć odpowiednie właściwości. Krashen ${ }^{37}$ wychodzi z założenia, że język można opanować receptywnie przez dostarczanie uczącym się danych językowych (inputu), które są dla nich przede wszystkim zrozumiałe (comprehensible input). Zrozumienie jest więc warunkiem przyswajania. Jeśli ten warunek nie zostanie spełniony, należy liczyć się z tym, że procesy sterujące percepcją

35 W. Butzkamm, Psycholinguistik des Fremdsprachenunterrichts, Tübingen - Basel 2002.

36 R. de Cillia, Progression im Fremdsprachenunterricht, [w:] Zweitsprachlernen in einem mehrsprachigen Gebiet. Grundlagen und Perspektiven für ein neues Curriculum, Bozen 1995, s. 205-215.

37 S. D. Krashen, op. cit. 
i przetwarzaniem danych językowych mogą zostać zablokowane bądź w ogóle nie zadziałać $^{38}$. Krashen twierdzi ponadto, że optymalny input, poza tym, że ma być zrozumiały, nie może podlegać progresji gramatycznej, musi być dla uczących się interesujący i znaczący oraz dostarczony w odpowiedniej ilości ${ }^{39}$. Zwracanie szczególnej uwagi na dane wejściowe w procesie glottodydaktycznym staje się postulatem również innych badaczy (Dakowska $2007^{40}$, Niżegorodcew 2009 ${ }^{41}$ ). Świadome koncentrowanie się nauczycieli na inpucie poprzez parafrazowanie wypowiedzi uczniów, powtarzanie ich produkcji językowych z pewnym rozszerzeniem bądź szczególnym zaakcentowaniem poprawnej formy oraz reagowanie w języku docelowym na pytania (nawet postawione przez uczniów w języku polskim), stało się również przedmiotem mojego badania.

Odsetek nauczycieli parafrazujących wypowiedzi uczniów, starających się mówić przy tym wolno i wyraźnie, przedstawia się następująco: bardzo często strategię taką stosowało $26 \%$ nauczycieli, często 20\%, czasami 30\%, rzadko $13 \%$, bardzo rzadko $6 \%$, nigdy 5\%. Bardzo podobne odpowiedzi zaznaczali respondenci przy stwierdzeniu: Nauczyciel powtarzał nasze odpowiedzi sformułowane w języku niemieckim. Jeśli były w nich błędy, powtarzał je w poprawionej, właściwej formie. Dodatkowo rozszerzał nasze wypowiedzi $w$ dwóch, trzech zdaniach.

Biorąc pod uwagę fakt, że parafrazowanie wypowiedzi uczniów oraz ich powtarzanie wraz z pewnym rozszerzeniem, uznać można za stosunkowo nieskomplikowaną, nie wymagającą specjalnego przygotowania, ale bardzo skuteczną metodę intensyfikacji inputu, to odpowiedzi respondentów mogą rozczarowywać. Nasuwa się po raz kolejny pytanie, z czego wynika brak wykorzystywania podstawowego narzędzia leżącego przecież, jak można domniemywać, w tzw. zasięgu ręki każdego nauczyciela.

Jeszcze mniejszy odsetek nauczycieli (według opinii respondentów) starał się odpowiadać po niemiecku na pytania zadane przez uczniów w języku polskim. Tylko 29\% germanistów postępowała w taki sposób bardzo często lub często, 23\% czasami, 33\% rzadko i bardzo rzadko, a 15\% nigdy. Wiadomo, że nie wszystkie pytania uczniów zadane w języku ojczystym powinny wywołać obcojęzyczną reakcję i od kiedy model lekcji prowadzonej przez native speakera przestał być modelem idealnym, nie ma wątpliwości co do tego, że zastosowanie języka ojczystego w niektórych sytuacjach jest w pełni uzasadnione. Z drugiej jednak strony, reagowanie $\mathrm{w}$ języku docelowym na określone pytania zadane przez uczniów w języku ojczystym, mogłoby przyczynić się do wykształcenia przyzwyczajeń

38 J. Iluk, Jak uczyć małe dzieci języków obcych?, Katowice 2002, s. 167.

39 S. D. Krashen, op. cit.

40 M. Dakowska, op. cit.

41 A. Niżegorodcew, op. cit. 
stosowania języka obcego w konkretnych sytuacjach. Konsekwencja nauczyciela w obcojęzycznych reakcjach na określone pytania uczniów być może mogłaby lepiej motywować do używania języka obcego przez uczniów niż eksplicytne prośby nauczyciela.

\section{Sposób prezentacji słownictwa}

W odpowiedzi na pytanie o prezentowanie nowych słów w formie listy słów niemieckich i ich polskich ekwiwalentów 20\% respondentów przyznaje, że ich nauczyciele nigdy z takowej listy nie korzystali. Tzw. listę słówek stosuje bardzo rzadko $13 \%$ nauczycieli, 10\% rzadko, $4 \%$ czasami i aż 30\% często oraz $23 \%$ bardzo często.

Jak widać, stosunkowo liczna grupa nauczycieli korzysta wciąż z tradycyjnej „listy słówek”. Nie negując zasadności sporadycznego korzystania z takiej formy prezentacji słownictwa i rozumiejąc specyficzne potrzeby uczniów, trudno się zgodzić, że stosowanie listy słówek przez ponad połowę nauczycieli często i bardzo często, jest pozytywnym zjawiskiem. Nie pozwala na to choćby stan współczesnej wiedzy. Permanentne stosowanie takiej formy przekazu (uderzającej w procesy przetwarzania informacji) uznać można za równoznaczne z ignorowaniem stylów uczenia się, rodzajów inteligencji i innych uwarunkowań osobowościowych uczniów, których nieuwzględnianie w procesie planowania procesu dydaktycznego, powoduje jego nieefektywność.

Ponadto stosowanie tzw. listy słów może wpływać negatywnie na proces przyswajania języka ze względu na wzmacnianie zjawiska habituacji bodźca ${ }^{42}$. Jak wiadomo, jednym z mechanizmów adaptacyjnych jest habituacja - przyzwyczajenie się organizmu do powtarzanego wielokrotnie bodźca, który nie ma istotnego znaczenia dla funkcjonowania organizmu w środowisku. W ten sposób działa wspomniana lista słówek, które są w najlepszym przypadku emocjonalnie obojętne uczącemu się. W końcu ile razy można „przerabiać” ten sam materiał, nie widząc większych rezultatów. Poprzez żmudne powtarzanie osiągamy efekt przeciwny do zamierzonego - nasz mózg traktuje dostarczane mu regularnie informacje pozbawione kontekstu związanego z aktualnym środowiskiem jako „szum informacyjny" i słusznie postanawia nie zaśmiecać nimi pamięci długotrwałej. Co innego, gdy ta sama lista słówek będzie stanowiła klucz do rozwiązania przez grupę problemu lub jej znajomość umożliwi ekspresję własnych opinii lub emocji. W takim kontekście społeczno-emocjonalnym ta sama grupa nowego słownictwa ma szansę zostać zapamiętana na długo. Innymi słowy, zjawisko habituacji nie

42 W. Bestrzyński, R. Szymiec, op. cit. 
ograniczy zapamiętywania wyrażeń, które znajdą się w interesującym kontekście i przy aktywnym ich użyciu w ramach interakcji społecznej ${ }^{43}$.

Analiza kolejnego punktu w ankiecie pozwala wnioskować na temat prezentacji nowych słów w różnych kontekstach. Zgodnie z otrzymanymi danymi, 20\% nauczycieli prezentuje nowe słownictwo w różnych kontekstach bardzo często, również 20\% często, 23\% czasami, 13\% rzadko, $20 \%$ bardzo rzadko i 4\% nigdy. Biorąc pod uwagę powszechność postulatu nauki języka obcego poprzez sytuowanie nowych słów w różnych kontekstach, trudno zrozumieć i zaakceptować, że polski kontekst edukacyjny nie odzwierciedla tych powszechnie znanych prawd nauki. 37\% (w sumie) nauczycieli nie umiejscawia nowych słów w różnych kontekstach (bądź czyni to rzadko lub bardzo rzadko). Biorąc pod uwagę również znany powszechnie fakt na temat asocjacyjnej pracy mózgu, tworzenia się połączeń nerwowych pod wpływem dostarczania informacji w kontekście właśnie, czy też prymarnej roli kontekstu w rozumieniu danych wejściowych, stwierdzić można, że aż tak liczna grupa nauczycieli skutecznie uniemożliwia swoim uczniom uruchamianie podstawowych procesów skutecznego przetwarzania informacji, gdyż słowa pozbawione kontekstu zdefiniowane zostaną przez mózg z dużym prawdopodobieństwem jako jednostki informacji abstrakcyjnej i wtedy takie wyrazy nie trafią do obszaru szybko dostępnej pamięci wykorzystywanej przez język, tylko do pamięci obiektów abstrakcyjnych - wolniej dostępnej i krócej podtrzymywanej ${ }^{44}$. Ponadto $\mathrm{w}$ dziedzinie przechowywania informacji wszystko, co nie jest odpowiednio często spotykane w środowisku i potrzebne do sklasyfikowania percepcji jest zapominane.

\section{Elementy podejścia narracyjnego}

Wprawdzie podejście narracyjne postrzegane jest przede wszystkim jako technika pracy w nauczaniu przedszkolnym i wczesnoszkolnym, to uważam, że stosowanie jego elementów jest pożądaną formą pracy na wszystkich etapach edukacyjnych ze względu na fakt, że jest ono dobrym źródłem inputu.

Odpowiedzi respondentów dostarczają informacji o znikomym stosowaniu podejścia narracyjnego na lekcji języka obcego z młodzieżą. 50\% studentów nigdy nie miała (będąc uczniami liceum) okazji uczestniczyć w zajęciach z zastosowaniem podejścia narracyjnego, $14 \%$ uczyła się w ten sposób bardzo rzadko, a 16\% rzadko. 20\% respondentów zadeklarowała, iż ich nauczyciele stosowali podejście narracyjne czasami. Taki wynik może budzić zdziwienie, szczególnie w obliczu faktu, iż konieczność zwana potocznie „osłuchiwaniem się” z językiem (co niewąt-

43 Ibidem, s. 168.

44 Ibidem. 
pliwie zapewnia podejście narracyjne) wydaje się być powszechnie usankcjonowana. Szukając przyczyn nikłego zastosowania podejścia narracyjnego w nauczaniu, można przytoczyć argument taki, że jest to przedsięwzięcie czasochłonne, z którego nauczyciele właśnie dlatego świadomie rezygnują. Inna możliwość to nieporadność nauczycieli lub po prostu nieumiejętność zastosowania tej metody. Współczesna dydaktyka szkolna mogłaby bardzo dużo zyskać wykorzystując w sposób właściwy podejście narracyjne w nauczaniu języków obcych, nie tylko na etapie wczesnoszkolnym.

Bardzo podobne wyniki uzyskano w odpowiedzi na pytanie o to, czy nauczyciel opowiadał krótkie anegdoty bądź też dowcipy w języku docelowym. Niewielkie różnice pojawiają się tylko w odpowiedziach rzadko i nigdy, co potwierdza wnioski z analizy wcześniejszego pytania. Nauczyciele rzadko dostarczają uczniom inputu zbliżonego do tego $\mathrm{z}$ warunków naturalnych. Koncentrują się raczej na inpucie mieszczącym się w ramach dyskursu klasowego, często sztucznego i nieprzystającego do rzeczywistości językowej kraju docelowego lub równie często przebiegającego w języku ojczystym.

\section{Zachęta do kreowania środowiska immersyjnego w warunkach innych niż lekcja}

Nawet jeśli usprawiedliwimy brak podejścia narracyjnego na lekcjach z młodzieżą brakiem czasu czy jego nieprzystawalnością do programu nauczania, to trudno zrozumieć brak stosowania zachęty ze strony nauczyciela do podejmowania przez uczniów takich działań, które umożliwiłyby intensyfikację inputu językowego poza klasą szkolną. Myślę tu o wskazywaniu „dobrego” kierunku działań, o zachęcaniu do samodzielnego czytania książek i prasy, oglądania filmów i programów niemieckojęzycznych czy też korzystania z komputera w wersji obcojęzycznej. Te współczesne możliwości, jak sądzę „przemawiające” do młodzieży, są wykorzystywane przez nauczycieli w bardzo ograniczonym zakresie. Tylko $4 \%$ nauczycieli zachęca swoich uczniów do podejmowania takich działań bardzo często, $16 \%$ często i $10 \%$ czasami. $33 \%$ nigdy nie zachęcała do dodatkowego kontaktu z językiem, 23\% nauczycieli czyniła to rzadko, a 14\% bardzo rzadko. Uważam, że potencjał mediów i powszechnie znany zapał młodzieży do korzystania z nich jest dobrym źródłem poszerzania spektrum metod optymalizujących jakość inputu.

\section{Teksty autentyczne jako źródło inputu}

Pytanie o teksty autentyczne na lekcji języka niemieckiego dostarcza wielu informacji odnośnie do językowych danych wejściowych na lekcjach języka niemieckiego. Praca z tekstami autentycznymi (tutaj piosenką i filmem) okazuje się mieć marginalne znaczenie. 40\% uczniów nigdy nie słuchało muzyki na lekcji języka niemieckiego, 27\% bardzo rzadko i kolejne 20\% rzadko. Czasami muzyki 
słuchało 13\%. Żaden respondent nie zaznaczył odpowiedzi często ani bardzo często. Jeszcze mniejszy odsetek miał okazję do słuchania „tekstów piosenek odpowiadających zainteresowaniom uczniów". 70\% respondentów zaznaczyła w tym przypadku odpowiedź nigdy, 16\% bardzo rzadko i 14\% rzadko. Innych odpowiedzi nie zaznaczono. Podobnie sytuacja przedstawia się w kwestii oglądania filmów niemieckojęzycznych. Odsetek osób, które nigdy nie oglądały filmu niemieckojęzycznego na lekcji stanowi $30 \%$ wszystkich badanych, bardzo rzadko taką okazję miało $23 \%$ respondentów, rzadko 16\%, czasami 16\%, często 12\% i 3\% bardzo często.

Nie korzystając z mediów nauczyciele odbierają uczniom niejednokrotnie jedyną możliwość kontaktu $\mathrm{z}$ autentycznym językiem obcym, a co za tym idzie możliwość zdefiniowania języka obcego jako narzędzia sensownej komunikacji. Nauczyciele eliminują tym samym jedną ze skuteczniejszych możliwości motywowania uczniów do podejmowania wyzwania, jakim jest uczenie się języka obcego. Dobre media zapewniając dobry input, są również częścią codziennej rzeczywistości uczniów, w związku z czym pewna ich „integracja z językiem obcym” mogłaby przynieść wymierne korzyści dla ucznia.

Ekspozycja uczniów na język obcy przez media nie jest jednak częstym zjawiskiem na lekcjach. To kwestia warta dalszych badań. Spekulować można, że powodem jest nieumiejętność wykorzystywania przez nauczycieli mediów w procesie glottodydaktycznym, brak motywacji do wyszukiwania odpowiednich materiałów czy też zbyt duża koncentracja na podręczniku i programie nauczania.

\section{Zabiegi metodyczne o małej wartości inputu}

$\mathrm{Za}$ „zabiegi metodyczne o małej wartości inputu” uznane zostało użycie form rutynowych i zadawanie pytań tzw. oczywistych. Okazuje się, że 59\% nauczycieli (w opinii respondentów) realizowała formy rutynowe w języku niemieckim bardzo często, 13\% często, 16\% czasami. Odpowiedzi bardzo rzadko, rzadko, nigdy udzieliło każdorazowo $4 \%$ badanych. Z punktu widzenia metodyki posługiwanie się formami rutynowymi w języku docelowym jest pozytywnym zjawiskiem. Natomiast pytania oczywiste nie są pożądaną praktyką. Z punktu widzenia skutecznego inputu jednak, żadne z tych działań nie wydaje się wpływać na optymalizację procesu glottodydaktycznego. Idzie o to, że powtarzane stale formy rutynowe przestają w pewnym momencie spełniać rolę właściwego inputu, tj. dostarczać nowych, zróżnicowanych danych wejściowych, na podstawie których można byłoby tworzyć i weryfikować własne hipotezy językowe. Stają się one zautomatyzowanymi zwrotami nie wymagającymi żadnej refleksji nad językiem, co nie jest złe, ale mało kształcące. Podobnie rzecz się ma z pytaniami tzw. oczywistymi (pytanie o imię, wiek, miejsce zamieszkania itd. na kolejnych lekcjach). Pytania oczywiste podważają sensowność komunikacji w ramach dyskursu klasowego, przez co mogą przyczynić się do spadku motywacji uczącego się. 
W przypadku badanych w analizowanej ankiecie 50\% stwierdza, że takich pytań nie słyszało nigdy lub bardzo rzadko, natomiast 33\% miało styczność z taką formą odpytywania bardzo często i często. Pozostałe 17\% badanych odpowiadało na takie pytania czasami lub rzadko.

\section{Podsumowanie}

Biorąc pod uwagę fakt, iż wszystkie rodzaje imersji prowadzą do głębokich zmian połączeń neuronowych, dokonywanych dla przetwarzania informacji językowej według nowego kodu ${ }^{45}$ oraz fakt, że język nabyty w procesach akwizycji (nieświadomie) jest łatwo dostępny w spontanicznej konwersacji, uważam, iż należy dokładać wszelkich starań, aby kreować środowiska klasowe bogate w input językowy.

Jak pokazują wyniki badań, opisani przez respondentów nauczyciele nie wydają się być ekspertami w tym zakresie. Uważam w związku z tym, że warto przeprowadzić bardziej szczegółowe badania w zakresie jakości danych wejściowych na lekcjach języków obcych, tak by móc stwierdzić faktyczny stan w tym zakresie w wymiarze bardziej globalnym oraz określić przyczyny ewentualnych braków w stosowaniu niewłaściwego inputu oraz zaproponować pewne rozwiązania. Uważam, że wnioski z takich badań mogą mieć znaczenie dla praktyki szkolnej oraz kształcenia przyszłych nauczycieli języków obcych.

\section{Bibliografia}

Auerbach E., Reaxamining English anly in the ESL classroom, „TESOL Quartely” 1993, 27 (1).

Berthoud A.-C., Py B., Des linguistes et des enseignants. Maîtrise et acquisition des langues seconds, Berne 1993.

Bestrzyński W., Szymiec R., Nauka języka obcego - drama jako składnik immersji, „Neodidagmata” 2008, 29/30.

Butzkamm W., Psycholinguistik des Fremdsprachenunterrichts, Tübingen-Basel 2002.

de Cillia R., Progression im Fremdsprachenunterricht, [w:] Zweitsprachlernen in einem mehrsprachigen Gebiet. Grundlagen und Perspektiven für ein neues Curriculum, Bozen 1995.

Clark E. V., First Language Acquisition, Cambridge 2003.

Cook V., Second language learning and language teaching (3rd ed.), London 2001.

Ellis R., The study of second language acquisition, Oxford 1994.

Dakowska M., Teaching English as a Foreign Language. A Guide for Professionals. Warszawa 2007.

Deller S., Rinvolucri M., Using the Mother Tongue, London-Addlestone 2002.

Eldridge J., Code - switching in a Turkish secondary school, „ELT Journal” 1996, 50 (14).

45 Ibidem. 
Ellis R., The study of second language acquisition, Oxford 1994.

Gass S., Input and interaction, [w:] Handbook of second language acquisition. C. J. Doughty, M. H. Long (red.), Oxford 2003.

Grabe W., Stoller F. L., Content-Based Instruction: Research Foundations, [w:] The Content-Based Classroom. Perspectives on Integrating Language and Content, M. A. Snow, D. M. Brinton (red.), White Plains, NY 1997.

Grucza F., Języki ludzkie a wyrażenia językowe, wiedza a informacja, mózg a umysł ludzki, [w:] Podejścia kognitywne w lingwistyce, translatoryce i glottodydaktyce, F. Grucza., M. Dakowska (red.), Warszawa 1997.

Iluk J., Jak uczyć małe dzieci języków obcych?, Katowice 2002.

Klein W., Second Language Acquisition, Cambridge 1986.

Krashen S. D., Principles and practice in second language acquisition, New York 1982.

Krashen S. D., The Input Hypothesis: Issues and Implications, New York 1985.

Lantolf J. Sociocultural theory and second language learning. Oxford 2000.

Littlewood W., Yu B. First language and target language in the foreign language classroom, „Language Teaching" 2011, 44 (1).

Long M. H., Linguistic and conversational adjustments to non-native Speakers, „Studies in Second Language Acquisition" 1983, 5.

Macaro E., Target language, collaborative learning and autonomy, Clevedon 1997.

Macdonald C., Using the target language, Cheltenham, UK 1993.

Nagy W., On the role of context in first- and second-language vocabulary learning. [w:] Vocabulary: description, acquisition and pedagogy, N. Schmitt, M. Mccarthy (red.), Cambridge 1997.

Niżegorodcew A., Input for instructed L2 learners: the relevance of relevance, Clevedon 2007.

Pawlak M., Rola nauczyciela w kształtowaniu procesów interakcyjnych podczas lekcji języka obcego, [w:] Nauczyciel języków obcych dziś i jutro, M. Pawlak, A. Mystkowska-Wiertelak, A. Pietrzykowska, Poznań-Kalisz 2009.

Prabhu N. S., Second language pedagogy, Oxford 1987.

Schmidt R., The role of consciousness in second language learning, „Applied Linguistics” 1990, 11.

Schmidt R., Attention, [w:] Cognition and second language instruction, P. Robinson (red.), Cambridge 2001.

Sharwood S., Smith M., Comprehension vs. acquisition: Two ways of processing input, „Applied Linguistics" 1986, vol. 7, nr 3.

Schweer W. J., Using L1 in the L2 classroom, „English Teaching Forum” 1999, 37 (2).

Swain M., Deters P., "New" mainstream SLA theory: expanded and enriched, „The Modern Language Journal" 2007, 9.

Turnbull M., There is a role for the L1 in second and foreign language teaching, but..., „The Canadian Modern Language Review" 2001, 57. 


\section{Załącznik nr 1}

Proszę zaznaczyć właściwą odpowiedź. Sformułowania proszę odnieść do swoich lekcji języka niemieckiego w liceum.

\begin{tabular}{|l|l|l|l|l|l|l|}
\hline & nigdy & $\begin{array}{c}\text { bardzo } \\
\text { rzadko }\end{array}$ & rzadko & czasami & często & $\begin{array}{c}\text { bardzo } \\
\text { często }\end{array}$ \\
\hline $\begin{array}{l}\text { Nauczyciel mówił na lekcji głównie } \\
\text { po niemiecku }\end{array}$ & & & & & & \\
\hline $\begin{array}{l}\text { Nauczyciel objaśniał nieznany materiał } \\
\text { gramatyczny w języku polskim }\end{array}$ & & & & & & \\
\hline $\begin{array}{l}\text { Nauczyciel tłumaczył nowe zwroty } \\
\text { leksykalne w języku niemieckim }\end{array}$ & & & & & & \\
\hline $\begin{array}{l}\text { Nauczyciel powtarzał nasze } \\
\text { odpowiedzi sformułowane w języku } \\
\text { niemieckim. Jeśli były w nich błędy, } \\
\text { powtarzał je w poprawionej, właściwej } \\
\text { formie. Dodatkowo rozszerzał nasze } \\
\text { wypowiedzi w dwóch, trzech zdaniach }\end{array}$ & & & & & & \\
\hline $\begin{array}{l}\text { Nauczyciel parafrazował/rozwijał nasze } \\
\text { wypowiedzi w języku niemieckim. } \\
\text { Mówił wtedy wolno i wyraźnie, tak } \\
\text { abyśmy mogli jak najwięcej zrozumieć }\end{array}$ & & & & & & \\
\hline $\begin{array}{l}\text { Nauczyciel starał się odpowiadać po } \\
\text { niemiecku na pytania zadane przez } \\
\text { uczniów w języku polskim }\end{array}$ & & & & & & \\
\hline $\begin{array}{l}\text { Nowe słowa prezentowane były } \\
\text { w formie listy słów - niemieckich } \\
\text { i ich polskich ekwiwalentów }\end{array}$ & & & & & & \\
\hline $\begin{array}{l}\text { Nauczyciel czytał nam/opowiadał } \\
\text { historyjki/książki w języku niemieckim } \\
\text { bez komentarzy gramatycznych i do- } \\
\text { kładnej analizy leksykalnej. Czytał dla } \\
\text { osłuchania się" z językiem }\end{array}$ & & & & & & \\
\hline $\begin{array}{l}\text { Nauczyciel opowiadał dowcipy/krótkie } \\
\text { anegdoty w języku niemieckim }\end{array}$ & & & & & & \\
\hline $\begin{array}{l}\text { Nauczyciel prezentował nam filmy } \\
\text { po niemiecku }\end{array}$ & & & & & & \\
\hline $\begin{array}{l}\text { Na lekcji słuchaliśmy niemieckiej } \\
\text { muzyki }\end{array}$ & & & & & & \\
\hline $\begin{array}{l}\text { Nauczyciel proponował nam pracę } \\
\text { z tekstami piosenek, które nas intere- } \\
\text { sowały }\end{array}$ & & & & & & \\
\hline
\end{tabular}




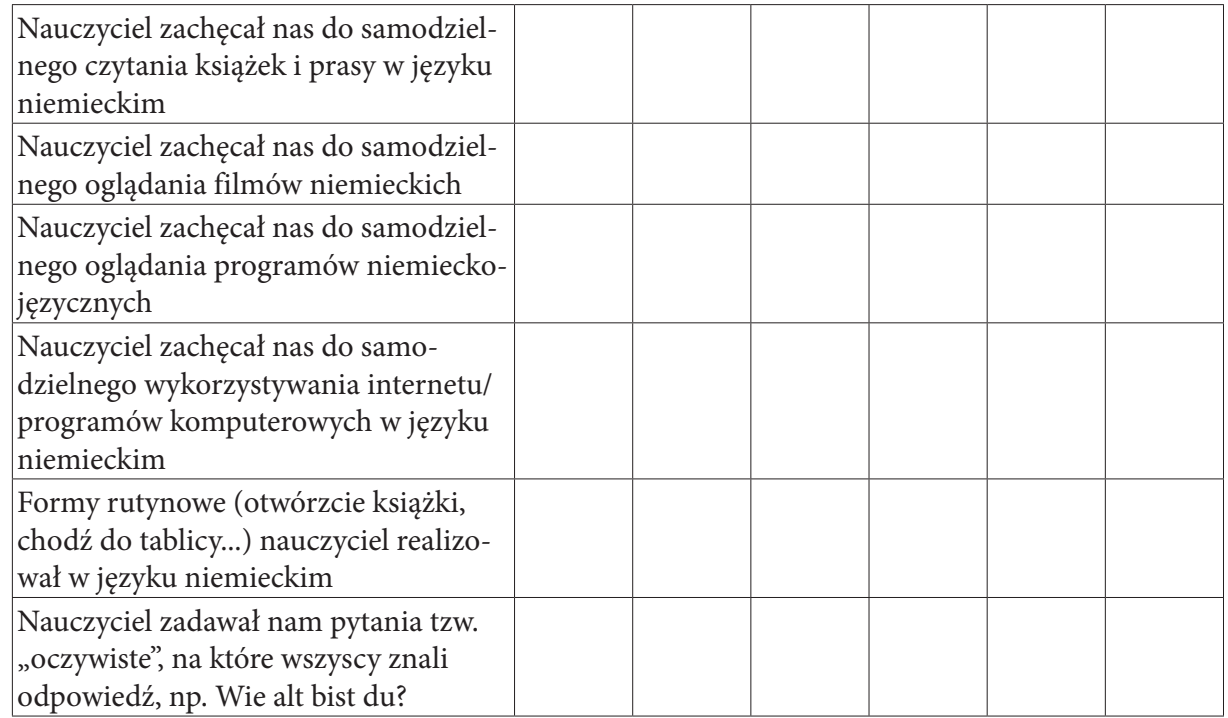

